\title{
ФОРМУВАННЯ
}

\section{КАТЕГОРІАЛЬНОГО АПАРАТУ}

НАУКИ ПРО ЕКОНОМІЧНУ БЕЗПЕКУ: СУЧАСНИЙ ЗРІЗ

\author{
Молдован Олексій Олександрович - \\ директор Центру політичних та економічних ініціатив \\ «Європейська стратегія», \\ докторант відділу економічної стратегії \\ центру економічних і соціальних досліджень \\ Національного інституту стратегічних досліджень, \\ кандидат економічних наук \\ ORCID: 0000-0002-3776-6291
}

У статmi обгрунтовується теза про те, що теорія економічної безпеки держави як наукова дисципліна сьогодні перебуває на початку якісно нового етапу розвитку, який характеризуватиметься посиленням наукового й прикладного інтересу до різних аспектів цієї тематики.

Ця тенденція відображає сучасну реальність, яка характеризується посиленням внутрішніх та зовнішніх загроз соціально-економічній стабільності у найбільших країнах світу, зростанням турбулентності у світовій економіці, посиленням глобальної конкуренції за природні ресурси й людський капітал та актуалізацією нових загроз економічній безпеці держави, зокрема таких як-от екологічна криза, неконтрольована міграція, пандемія коронавірусу тощо.

Наголошено на тому, що наукова спільнота найближчим часом зіштовхнеться з необхідністю вирішення низки важливих завдань щодо формування оновленої методологічної основи, верифікації напрацьованих знань та окреслення нових пріоритетів наукових досліджень. Ці завдання буде досить складно вирішити без комплексу універсальних дефініцій, які дозволяють максимально об'єктивно описати феномен економічної безпеки держави.

Акцентовано на тому, що високий рівень герметизації наукових шкіл та їх постійне прагнення до формування власного категоріально-понятійного апарату $є$ серйозною проблемою для розвитку теорії економічної безпеки держави як самостійної наукової дисципліни. Зазначена проблема унеможливлює формування спільної методологічної основи та підриває можливість конструктивної наукової дискусії між представниками різних наукових шкіл.

У цьому контексті зроблено спробу систематизації та впорядкування категоріально-понятійного апарату. В рамках цього завдання проаналізовано науковий доробок кількох десятків наукових шкіл та окремих знаних фахівців, які працюють над проблематикою економічної безпеки держави. Обгрунтовано низку базових дефініцій, що мають перспективу стати універсальними в рамках екосестейту. 
Звернено увагу на те, що поряд із впорядкуванням понятійного категоріального апарату важливим завданням $€$ його періодичний перегляд з метою уточнення й удосконалення. Сучасний етап розвитку екосестейту характеризується послабленням неоліберальних ідей та посиленням впливу на наукову спільноту економічних концепцій неореалізму. Це помітно впливає на категоріально-понятійний апарат, яким послуговується наукова спільнота цієї дисципліни. У зв'язку з цим система актуальних базових дефініцій екосестейту потребує змістовного перегляду й уточнення з урахуванням нових реалій сьогодення.

Ключові слова: теорія економічної безпеки держави (екосестейт), економічна безпека держави, об'єкт економічної безпеки держави, суб’єкт економічної безпеки держави, системні загрози.

\section{Aleksy Moldowan \\ A CONCEPTUAL APPARATUS FOR THE FIELD OF NATIONAL ECONOMIC SECURITY: AN UPDATED VIEW}

The author argues that the theory of national economic security is on the rise again and the qualitatively new phase of its development will be characterized by an increase of scientific and applied interest to various aspects of this field.

This trend is consistent with the escalation of internal and external threats to socio-economic stability in major countries, the growing turbulence in the global economy, intensified global competition for natural resources and human capital and the emergence of new types of threats to national economic security, including environmental crises, uncontrolled migration and the coronavirus pandemic.

In the near future, the scientific community will face a number of important research tasks, including the need to shape an updated methodological base, verify acquired knowledge and outline new research priorities. These tasks will be difficult to complete without a set of comprehensive definitions in the field of national economic security.

The ongoing capsulation of scientific schools and their gravitation toward their own conceptual frameworks is a serious problem for the institutionalization and development of national economic security as an independent scientific discipline. This problem makes it impossible to create a common methodological framework for the discipline and undermines constructive scientific discussion between representatives of different scientific schools in this field.

The author attempts to streamline the conceptual apparatus to solve the aforementioned problem. The scholarship of several scientific schools and prominent experts is analyzed to identify and systematize the most important terms and their definitions within the field of national economic security. Based on the data obtained a number of comprehensive and coherent definitions is introduced.

The current stage of the evolution of national economic security is characterized by a weakening of neoliberal ideas and an increased impact of economic concepts within neorealism in the scientific community. These developments need to be reflected in the conceptual apparatus of this discipline. In this regard, the system of current basic definitions requires a significant update.

Keywords: theory of national economic security, national economic security, object of national economic security, subject of national economic security, system threats.

Останніми роками у світовій та, зокрема, в український науковій спільноті спостерігається помітне підвищення інтересу до проблематики теорії економічної безпеки держави (екосестейту). Така тенденція є відтворенням реалій сучасної епохи, що характеризується посиленням внутрішніх i зовнішніх загроз для соціально-економічної стабільності держави як найбільш поширеного 
інституту організації суспільства. Внутрішні економічні дисбаланси, зростання турбулентності в глобальній економіці, загострення світової конкуренції за природні ресурси та людський капітал, актуалізація низки нових проблем (екологічна криза, неконтрольована міграція, пандемія коронавірусу тощо) створюють не просто проблеми, а системні загрози для економічної безпеки держави. За таких обставин наукова спільнота шукає ефективні механізми забезпечення економічної безпеки держави.

Активізації досліджень у зазначеній науковій сфері вимагає формування твердої методологічної бази, основу якої становить систематизований, упорядкований та чітко окреслений категоріально-понятійний апарат. У цьому питанні перед науковою спільнотою, яка досліджує проблематику в рамках екосестейту, виникла низка серйозних перешкод. Одна з ключових проблем полягає в тому, що теорії економічної безпеки як науковій дисципліні притаманний високий рівень фрагментації. У рамках цього напряму економічних досліджень активно розвивається значна кількість наукових шкіл, кожна з яких досить часто використовує власну термінологію, опрацьовану спеціально для вирішення власних наукових завдань.

Термінологічний хаос унеможливлює формування спільної методологічної основи в рамках означеної наукової дисципліни та підриває можливість конструктивної наукової дискусії між представниками різних наукових шкіл. Термінологічна різнорідність не $є$ критичною проблемою для становлення науки, але вона не повинна призводити до абсолютно різного розуміння базових дефініцій, на яких формується екосестейт. У зв'язку з цим у контексті активізації досліджень у рамках теорії економічної безпеки держави одним із найбільш важливих завдань сьогодення $є$ систематизація та впорядкування базових термінів, що використовуються в дослідженнях у межах зазначеної наукової дисципліни.

У світовій науковій думці є група науковців, праці яких можна вважати фундаментальними для теорії економічної безпеки держави (Б. Бузан, В. Кейбл, Г. Маховскі, Х. Мауль, С. Мардок, П. Робінсон, Б. Тейлор та ін.). Варто, однак, зазначити, що в західній науковій думці абсолютна більшість учених зосереджена на дослідженнях певних досить вузьких аспектах економічної безпеки держави, через те приділяють незначну увагу впорядкуван- ню термінології, яку вони використовують у своїх дослідженнях.

В Україні також створено власну потужну школу, яка досліджує різні аспекти економічної безпеки держави (В. Горбулін, Я. Жаліло, О. Власюк, 3. Варналій, А. Сухоруков та ін.). Саме в наукових працях українських фахівців можна знайти спроби систематизації та впорядкування категоріально-понятійного апарату. Класичною в цій сфері є праця «До формування категоріального апарату науки про економічну безпеку» [1], написана знаним українським науковцем Я. А. Жалілом у період активного становлення теорії економічної безпеки держави в Україні. У вказаному дослідженні запроваджено систему базових термінів екосестейту, які стали загальноприйнятими в значній кількості вітчизняних наукових шкіл, котрі провадять дослідження в рамках науки про економічну безпеку держави.

Наразі розпочинається новий етап розвитку екосестейту, що характеризується посиленням впливу ідей неореалізму.

Це потребуватиме перегляду й оновлення методологічної основи, верифікації напрацьованих знань та визначення нових пріоритетів наукових досліджень. Першочерговим завданням у цьому контексті має стати уточнення й оновлення системи базових дефініцій теорії економічної безпеки.

Отже, метою статті є спроба систематизації та впорядкування категоріально-понятійного апарату екосестейту з урахуванням специфіки нового етапу їі розвитку.

Як зазначено вище, характерною рисою і специфікою теорії економічної безпеки держави $€$ те, що в ії рамках функціонує значна кількість самостійних наукових шкіл. Кожна 3 них послуговується стандартним набором базових термінів цієї дисципліни, проте часто вкладає в них різний зміст.

Принципові розбіжності між різними школами та окремими науковцями виявляються вже на стадії трактування базового поняття дисципліни - «економічна безпека держави». На підставі аналізу різних дефініцій можемо виокремити шість основних поширених підходів щодо визначення цього терміна. Їх подано нижче в таблиці. 
Таблиця. Найбільш поширені підходи щодо визначення терміна «економічна безпека держави»

\begin{tabular}{|c|c|c|}
\hline Назва підходу & Визначення терміна & Учені, які презентують підхід \\
\hline Кондиціональний & $\begin{array}{l}\text { Сукупність певних умов, } \\
\text { які забезпечують реалізацію визначених } \\
\text { державою завдань }\end{array}$ & $\begin{array}{l}\text { Л. Абалкін [2, с. } 5] \text {, } \\
\text { А. Іларіонов }[3, \text { с. } 35], \\
\text { С. Пирожков [4, с. } 14], \\
\text { А. Сухоруков [5, с. } 53] \\
\text { О. Ляшенко [6, с. } 43-44]\end{array}$ \\
\hline Якісний & $\begin{array}{l}\text { Найважливіша якісна характеристика } \\
\text { економічної системи, що визначає ї̈ здатність } \\
\text { підтримувати нормальні умови функціонування } \\
\text { та діяльності її ключових учасників - держави, } \\
\text { бізнесу та громадян }\end{array}$ & $\begin{array}{l}\text { Я. Жаліло [1, с. 102], } \\
\text { Й. Янг [7, с. 67], } \\
\text { М. Єрмошенко [8, с. 29], } \\
\text { Б. Губський }[9, \text { с. 17] }\end{array}$ \\
\hline Протекціоністський & $\begin{array}{l}\text { Захищеність держави, бізнесу } \\
\text { та громадян від внутрішніх } \\
\text { і зовнішніх загроз }\end{array}$ & $\begin{array}{l}\text { В. Савіна[10, с. } 23] \text {, } \\
\text { Т. Сак }[11, \text { с. } 337] \text {, } \\
\text { В. Сенчагов }[12, \text { с. } 99]\end{array}$ \\
\hline Статичний & $\begin{array}{l}\text { Стан економіки, який дозволяє державі } \\
\text { реалізовувати її функції } \\
\text { та протидіяти зовнішнім } \\
\text { і внутрішнім загрозам }\end{array}$ & $\begin{array}{l}\text { Г. Пастернак-Таранушенко [13, с. } 29] \text {, } \\
\text { В. Шлемко та I. Бінько }[14, \text { с. } 8], \\
\text { В. Андрійчук }[15, \text { с. } 14], \\
\text { 3. Стаховяк }[16, \text { с. } 189] \text {, } \\
\text { К. Рачковскі }[17, \text { с. } 81]\end{array}$ \\
\hline Ресурсний & $\begin{array}{l}\text { Ресурсно-функціональна } \\
\text { та інституційна спроможність держави своєчасно } \\
\text { протистояти загрозам в умовах постійних змін } \\
\text { економічного середовища, забезпечувати захист } \\
\text { національних інтересів }\end{array}$ & $\begin{array}{l}\text { I. Губарєва [18, с. } 31] \\
\text { М. Флейчук та Я. Гончарук }[19, \text { с. } 18] \text {, } \\
\text { В. Бойко [20, с. } 165]\end{array}$ \\
\hline Телеологічний & $\begin{array}{l}\text { Безпека не є сприятливим збігом обставин, } \\
\text { а результатом свідомої } \\
\text { та цілеспрямованої діяльності щодо досягнення } \\
\text { такого стану }\end{array}$ & $\begin{array}{l}\text { В. Предборський, [21, с. 13], } \\
\text { В. Мунтіян [22, с. 10] }\end{array}$ \\
\hline
\end{tabular}

Джерело: складено автором на основі [1-22].

Аналізуючи наведені вище підходи щодо визначення економічної безпеки держави, доходимо висновку, що кожен із них акцентує увагу на одному 3 важливих аспектів цього поняття, тому не можна стверджувати, що якісь із цих підходів $\epsilon$ правильними, а інші - помилковими. Проблема полягає в тому, що більшість із цих визначень, хоча й досить влучно описують феномен економічної безпеки в рамках певної наукової школи, усе ж не можуть бути використані для дослідження в рамках інших наукових шкіл через відмінний зміст, який вкладається тими чи тими науковцями в це поняття.

Ураховуючи зазначене вище, вважаємо, що проведення наукових досліджень вимагає впровадження чітко сформованих дефініцій, які були б загальноприйнятими в межах цієї наукової дисципліни. Тому пропонуємо авторське визначення базового терміна екосестейту. Звертаємо увагу на те, що під час опрацювання підходу до визначення «економічна безпека держави» було враховано кілька важливих аспектів.
По-перше, ключовим чинником, який зумовив зародження й розвиток теорії економічної безпеки держави, є поняття «загроза». Симптоматично, що сплеск наукового й політичного інтересу до цього напряму досліджень досить щільно корелюється зі збільшенням кількості та інтенсифікацією зовнішніх і внутрішніх загроз для стабільності держави в різних (військовій, політичній, економічній, соціальній тощо) сферах. У зв'язку з цим завдання протидії загрозам різного характеру має стати наріжним каменем забезпечення економічної безпеки держави.

По-друге, багато термінів, якими оперують фахівці для визначення поняття «економічна безпека держави», є досить складні для використання у наукових дослідженнях. Зокрема, доволі важко об'єктивно оцінити та охарактеризувати «здатність» економічної системи до протидії загрозам. Значні проблеми створює також оперування такою характеристикою як «захищеність» економічної системи. Нині в рамках теорії економічної безпеки відсутній методологічний інструментарій, 
який дозволив би здійснити якісний та кількісний аналіз «стану захищеності» економіки щодо зовнішніх і внутрішніх загроз.

Крім того, «захищеність» передбачає певну пасивність і статичність держави щодо оточуючого середовища, тоді як актуалізація нових загроз вимагає активних свідомих дій щодо їх нейтралізації. 3 нашої точки зору, держава повинна не лише захищати економіку, а й активно протидіяти викликам, які в майбутньому можуть трансформуватись у небезпечні загрози.

По-третє, економічна безпека держави є складовою частиною національної безпеки держави. Спроби виокремлення ii як абсолютно незалежної сфери та автономної наукової дисципліни, що зосереджена на вирішенні економічних проблем, не мають сенсу - вони дублюватимуть напрацювання в рамках загальної економічної теорії. Політика забезпечення економічної безпеки держави має корелювати із завданнями національного масштабу.

Зазначимо, що не кожна економічна проблема створює загрози для економічної безпеки держави, тому їх потрібно чітко розмежовувати. У центрі уваги економічної безпеки держави мають перебувати лише ті проблеми, що формують критичні та системні загрози для держави як соціально-політичного інституту. Натомість проблеми, що не становлять загроз для економічної безпеки, мають бути об'єктом реагування в рамках поточної соціально-економічної політики держави.

Отже, враховуючи вищевикладені аргументи, економічну безпеку держави, на нашу думку, варто розглядати як свідомо та цілеспрямовано скоригований у бажаному напрямі органами публічної влади стан економіки, який забезпечує стійкість держави до зовнішніх і внутрішніх системних загроз та цілеспрямованих актів інших держав, спрямованих на її дестабілізацію.

На користь такого підходу щодо визначення поняття «економічна безпека держави» можна навести значну кількість аргументів, але найважливішим $€$ те, що аналізувати та емпірично оцінювати «стан» економіки можна набагато точніше та об’єктивніше, ніж «здатність» чи «захищеність» економіки. Окрім того, таке трактування економічної безпеки держави є зручнішим для використання на політико-прикладному рівні, оскільки дає можливість окреслити значення індикаторів такого стану економіки, досягнення й утримання яких є завданням політики щодо забезпечення високого рівня економічної безпеки держави.

При цьому, визначаючи економічну безпеку держави як певний цілеспрямовано скоригований стан економіки, підкреслюємо, що він не $є$ випадковим збігом обставин чи довільно обраною сукупністю чинників. Цей стан $є$ результатом реалізації комплексу заходів державної політики та свідомого створення певних умов, за яких національна економіка здатна протидіяти зовнішнім і внутрішнім загрозам.

Окрім консенсусу у справі визначення поняття «економічна безпека держави», формування методологічних засад дисципліни вимагає чіткого погодження в науковій спільноті системи базових дефініцій, які мають органічно та гармонійно розкривати феномен економічної безпеки. Зокрема, це низка таких понять: «об'єкт економічної безпеки держави», «суб'єкт забезпечення економічної безпеки держави», «загроза економічній безпеці держави», «системна загроза економічній безпеці держави», «джерело загрози економічній безпеці держави», «виклик економічній безпеці», «ризик економічній безпеці», «збитки економічній безпеці».

Поняття «об’єкт економічної безпеки держави» закономірно залежить від змісту дефініції «економічна безпека держави», яку взяла на озброєння конкретна наукова школа. Наприклад, якщо іiі фахівці трактують економічну безпеку як певну «здатність» економіки, то об’єкт буде розкриватися через аналогічну категорію. Подібна ситуація простежується в більшості наукових шкіл, унаслідок цього в українській науковій думці існує значна кількість різних підходів щодо визначення об'єкта економічної безпеки держави. Їх досить гармонійно використовують для розбудови методологічних засад відповідних наукових шкіл, але проблема полягає в тому, що ці визначення можуть бути корисними лише в рамках наукової діяльності окремої наукової школи.

Також суттєвою проблемою є те, що досить часто науковці в дефініції поняття об’єкта економічної безпеки держави намагаються охопити максимально широкий перелік різних аспектів (зокрема, це стан економіки держави, природні ресурси і територія, суб'єкти господарювання, суспільство, сім'я, громадяни та ін.). Так, автори монографії «Економіка та економічна безпека держави: теорія та практика» до об’єктів економічної безпеки України відносять не лише державу, іiі економічну 
систему та всі їі природні багатства, а й суспільство 3 усіма його інститутами, навіть особистість $[23$, с. 22].

У подібному руслі В. Духов формулює власне визначення об'єкта економічної безпеки держави. Під ним він розуміє систему економічних відносин суспільства і державний сектор економіки, які забезпечують передумови досягнення макроекономічних цілей розвитку, підвищення рівня та якості життя населення на основі економічного зростання, стабільності грошово-фінансової системи і зайнятості населення [24, с. 158].

Досить широким є підхід фахівців із Харківського національного університету імені В. Н. Каразіна, які працювали над монографією «Економічна безпека держави: сутність та напрями формування». Відповідно до нього «об'єкт економічної безпеки»- це те, що безпосередньо потребує захисту і на що спрямовані дестабілізуючі дії [25, c. 15]. При цьому автори додають, що економічна безпека держави має не лише власний об’єкт (економічну систему країни), але й об'єкти на стику з іншими можливими сферами: військовою, громадською, екологічною, інформаційною, криміногенною та ін. Додатково об'єкти економічної безпеки держави науковці пропонують поділяти на матеріальні та неречові. Під першими розуміють сфери зовнішньоекономічних інтересів, натомість неречовими об'єктами називають цінності, потреби, інтереси, плани тощо, тобто елементи суспільної свідомості.

Наведені визначення об'єкта економічної безпеки, безперечно, досить змістовно описують це поняття та допомагають зрозуміти його важливі аспекти, але вони є надмірно складними для використання в наукових дослідженнях, особливо тих, які мають політико-прикладне значення.

Оскільки нами було обгрунтовано, що найбільш оптимальним варіантом у наукових дослідженнях, у т. ч. політико-прикладного рівня, є застосування базових методологічних засад наукової школи, яка трактує економічну безпеку держави як стан економіки, зміст поняття «об’єкт економічної безпеки держави» має органічно випливати 3 відповідної дефініції. У межах цього підходу об'єктом економічної безпеки держави у найбільш загальному розумінні є економічна система держави. О. Власюк додає, що об'єкт економічної безпеки країни - це той стан економіки, який бажано зберегти або розвивати суспільству в наростаючих масштабах [26, с. 13], маючи на увазі те, що об'єктом є такий стан економіки, який забезпечує стійкість держави до загроз. Значна кількість українських економістів узяла на озброєння цей підхід. Вони модифікують у різний спосіб дефініцію «об’єкт економічної безпеки», але дотримуються думки, що це є певний бажаний стан економіки.

Погоджуючись із таким підходом у цілому, вважаємо за потрібне зробити певні уточнення. На нашу думку, під поняттям «об'єкт економічної безпеки» належить розуміти певний стан економіки, який можна описати через конкретні економічні показники та індикатори. Натомість поняттям «забезпечення економічної безпеки» потрібно позначати систему свідомих і цілеспрямованих дій органів державного управління (суб'єктів економічної безпеки), що спрямовуються на досягнення бажаного стану економіки, тобто такого, який забезпечує стійкість держави до системних загроз та цілеспрямованих актів агресії. На політико-прикладному рівні забезпечення економічної безпеки держави має спрямовуватися на досягнення таких показників та індикаторів економіки, за яких актуалізація загроз не призводить до критичних тенденцій.

У цьому контексті вважаємо за необхідне відмовитися від практики надмірного розгалуження поняття «забезпечення економічної безпеки держави». Подібний підхід домінує, серед іншого, у Методичних рекомендаціях щодо розрахунку рівня економічної безпеки України. У цьому документі зазначається, що в рамках забезпечення економічної безпеки держави влада має реалізувати цілий комплекс заходів, серед них:

- гарантування механізмів, що забезпечують стійкість економіки до внутрішніх і зовнішніх загроз;

забезпечення високої конкурентоспроможності економіки усвітовому економічному середовищі;

— забезпечення сталого та збалансованого зростання національної економіки [27].

3 нашого погляду, такий підхід призводить до розмивання політики забезпечення економічної безпеки, яка фактично розчиняється в поточній економічній політиці держави. Якщо об'єктом економічної безпеки держави є економічна система держави, то забезпечення економічної безпеки держави повинно фокусуватися на формуванні iii стійкості щодо зовнішніх і внутрішніх (т. зв. системних) загроз, які можуть спричинити кри- 
тичні тенденції в економіці держави та підірвати ефективність державних базових інститутів.

Значні термінологічні розбіжності в українській науковій думці спостерігаються й щодо визначення суб'єктів забезпечення економічної безпеки (часто також уживається термінологічне сполучення «суб'єкти економічної безпеки»). У багатьох наукових працях простежується тенденція щодо включення до цієї категорії досить широкого переліку суб’єктів: держави, окремих суб’єктів господарювання і навіть громадян. 3 нашого погляду, такий підхід деперсоналізує суб'єкт економічної безпеки держави й розмиває відповідальність за іiі забезпечення.

Для внесення ясності в питання термінології необхідно сформулювати чітку думку стосовно того, що суб'єктом забезпечення економічної безпеки держави може бути лише держава в особі уповноважених органів та інституцій публічної влади, які розробляють відповідне нормативно-правове підгрунтя у сфері забезпечення економічної безпеки держави та забезпечують реалізацію цього напряму державної політики із залученням необхідних для цього ресурсів.

Важливим завданням із впорядкування категоріально-понятійного апарату є розмежування та чітке визначення понять «виклики», «ризики» та «загрози». У цьому питанні серед фахівців теж немає одностайності. В західній науковій думці широко використовується набір спеціалізованих термінів для вимірювання рівня шкідливого впливу певного явища чи події, серед яких найпоширенішими $€$ «ризик» (risk), «небезпека» (hazard), «загроза» (threat). У загальній безпекології ці поняття розрізняються, проте в західних школах теорії економічної безпеки вони зазвичай трактуються досить спрощено з огляду на те, що екосестейт $є$ переважно прикладною дисципліною. Досить часто всі зазначені поняття використовуються як синоніми.

Натомість східноєвропейські фахівці, навпаки, намагаються надати кожному з цих термінів індивідуальний зміст. Так, С. Кортунов розглядає ризики, виклики і загрози як різні ступені небезпеки. У цьому термінологічному ряді ризики найнижчий рівень небезпеки, а загрози - найвищий [28, с. 23]. На наш погляд, такий підхід $€$ надто складним для застосування в рамках наукових досліджень, оскільки в ньому відсутні чіткі критерії розмежування того, де $є$ найнижчий рівень небезпеки, а де починається найвищий. Загалом, на сучасному рівні розвитку теорії еко- номічної безпеки опрацювання комплексу таких критеріїв, які дозволили 6 емпірично диференціювати рівень небезпеки, видається досить складним завданням.

Ми дотримуємося підходу, відповідно до якого ризики, виклики і загрози мають різний зміст. Як зазначено вище, ключовим елементом, через який розкривається суть економічної безпеки держави, є поняття «загрози економічній безпеці». У науковій літературі, що присвячена дослідженням у рамках цієї тематики, досить часто робиться акцент на описі та каталогізації актуальних економічних проблем, які, на думку вчених, є загрозами економічній безпеці держави. Натомість менше уваги приділяється концептуальному аналізові поняття «загроза», яке фактично є критерієм розмежування поточної економічної політики держави та політики забезпечення економічної безпеки.

У найбільш загальному розумінні поняття «загроза» трактується як можлива небезпека, що виникає за негативних змін у зовнішньому політичному, економічному або природному середовищі, а також негативних змін в аналогічних процесах і сферах всередині країни [29, с. 928]. У світовій і в українській науковій думці наразі існує кілька різних підходів щодо визначення цього поняття та щодо ролі загроз у системі економічної безпеки держави. Наприклад, В. Сенчагов опрацював цю дефініцію, опираючись на визначення національних інтересів. Він зазначає, що система економічної безпеки як на загальнодержавному, так і на регіональному рівні будується на основі тріади «інтереси - загрози - захист». Якщо національні економічні інтереси захищені від деструктивного впливу різного роду загроз, забезпечується найвищий рівень економічної безпеки національної економіки. У випадку недостатнього рівня захисту національних економічних інтересів від небезпечного впливу економічних загроз має місце протилежна, небезпечна ситуація в економічній системі держави [12, с. 99].

Своєю чергою, Е. Олейников під загрозами економічній безпеці розуміє «явні чи потенційні дії, що ускладнюють або унеможливлюють реалізацію національних економічних інтересів і створюють небезпеку для соціально-економічної та політичної системи, національних цінностей, життєзабезпечення нації та окремої особи» [30, с. 64]. Згідно з визначенням Л. Гончаренка, загрози економічній безпеці держави - це негативні зміни у зовнішньому політичному, економічному або природному 
середовищі, які завдають реальну чи потенційну шкоду державі в цілому, їі структурним елементам та безпосередньо життєвим, політичним, економічним інтересам громадян країни [31].

У науковій думці існує також підхід, згідно з яким загрози економічній безпеці це не потенційні умови чи ймовірна небезпека, а відповідний стан економіки. Зокрема Е. Румянцева стверджує, що загроза економічній безпеці держави - це стан економіки, за якого держава внаслідок внутрішніх та зовнішніх чинників втрачає контроль над виробництвом і обігом та базовими економічними й правовими важелями впливу на них [32].

Аналізуючи зазначені підходи, знову стикаємось із проблемою широкого діапазону дефініцій, тому що кожна наукова школа намагається виробити власний, відмінний від інших, категоріально-понятійний апарат. Відповідно, практично кожна 3 них сформувала власне визначення поняття «загроза економічній безпеці». Проте, на наше глибоке переконання, для здійснення наукових досліджень у рамках теорії економічної безпеки держави необхідно мати чітке бачення й розуміння загроз економічній безпеці держави, їх природи та джерел. У зв'язку із цим необхідно врахувати кілька важливих методологічних уваг.

По-перше, з нашого погляду, важливість поняття «загроза економічній безпеці економіки» полягає в тому, що воно дозволяє провести певну інституційну межу між загальною економічною теорією та теорією економічної безпеки держави. Особливо гостро це питання постає, коли йдеться про політику держави. Досить важливим питанням $€$ розмежування соціально-економічної політики держави та політики забезпечення економічної безпеки держави. На наш погляд, саме коректне впровадження поняття «загроза економічній безпеці держави» є тим критерієм, який дозволяє вирішити цю проблему.

Відповідно до такого підходу економічна політика держави має бути сфокусована на вирішенні загальних завдань соціально-економічного розвитку, які окреслюються кожною державою відповідно до системи іiі пріоритетів. Натомість політика забезпечення економічної безпеки починається тоді, коли виникають загрози, здатні підірвати функціонування базових економічних інститутів. Інакше кажучи, політика забезпечення економічної безпеки повинна мати на меті протидію загрозам, що становлять небезпеку для держави в цілому.
По-друге, загроза економічній безпеці повинна мати конкретну матеріалізовану форму та загрожувати реальними деструктивними наслідками. Відповідно до цього вважаємо, що загрози економічній безпеці держави не можуть бути аморфними, вони піддаються ідентифікації та чіткому визначенню. Наслідками їх актуалізації $є$ конкретні збитки для держави.

3 метою виокремлення категорії загроз, що несуть потенційну небезпеку для економіки як системи, реагування на які потребує реалізації комплексу заходів на рівні вищих органів державного управління, пропонуємо запровадження поняття «системна загроза». Під ним варто розуміти певні стихійні або штучно створені події та явища, наслідки яких можуть призвести до дестабілізації соціально-економічної ситуації у країні та порушення функціонування базових економічних інститутів, що, своєю чергою, призведе до критичного погіршення ефективності реалізації державою своїх базових функцій.

Загрози можна класифікувати за різними ознаками, зокрема поділяючи на: внутрішні та зовнішні, реальні та потенційні, безпосередні та опосередковані, цілеспрямовано створені будь-яким суб'єктом або ж такі, що виникають стихійно, тощо. 3 нашого погляду, на методологічному рівні каталогізація та деталізація конкретних загроз економічній безпеці держави не має практичного змісту, оскільки, як слушно зазначає Т. Мкртчян, постійні зміни у світі, що відбуваються навколо політичних, економічних, соціальних, військових та інших питань, також постійно змінюють характер і зміст загроз економічній безпеці [33, с. 12].

Переконані, що ця частка теорії та політики забезпечення економічної безпеки потребує лише спільних принципів і методик. Натомість ідентифікація конкретних загроз повинна здійснюватися в індивідуальному порядку, з урахуванням специфіки кожної держави, а також обставин, у яких вона функціонує. Це завдання, які мають вирішуватися на аналітичному рівні. Кожна держава повинна самостійно визначити й систематизувати загрози у сфері економічної безпеки, які можуть мати для неї критичні наслідки.

Виходячи 3 того, що під загрозами економічній безпеці держави розуміємо події та явища, джерелами загроз варто вважати локалізовані у простоpi та часі умови та обставини, у яких вони формуються й розвиваються, створюючи небезпеку для конкретної держави. 
Щодо впорядкування термінів «виклик» та «ризик» дотримуємося такого підходу. Повністю погоджуємось із досить чіткою та простою для використання під час наукового дослідження дефініцією поняття «виклик», яку запропонував О. Сергунін. Відповідно до його підходу під цим поняттям слід розуміти «сукупність обставин, не обов'язково загрожувального характеру, але, безумовно, таких, що вимагають реакції» [34, с. 127].

Натомість поняття «ризик» у науковій літературі отримало кілька абсолютно різних трактувань. Так, А. Кузьменко окреслює це поняття як «початкову, найчастіше віртуальну стадію несприятливих умов для безпеки та національних інтересів» [35], В. Пироженко - як міру небезпеки, що є похідною від ступеня ймовірності небажаної події та розміру можливих втрат за їі настання [36, с. 32]. У свою чергу, В. Вітлінський та Г. Великоіваненко характеризують ризик як економічну категорію, яка «.. відображає особливості сприйняття заінтересованими суб'єктами економічних відносин об'єктивно існуючих невизначеності та конфліктності, іманентних процесам цілепокладання, управління, прийняття рішень, оцінювання, що обтяжені можливими загрозами і невикористаними можливостями» $[37$, с. 5$]$.

3 нашого погляду, як спрощений підхід західних наукових шкіл, так і надмірне бажання до ускладнення та індивідуалізації категоріально-понятійного апарату східноєвропейських фахівців у галузі економічної безпеки держави, не дають змоги повною мірою розкрити сутність ризику економічній безпеці держави та визначити його в теорії економічної безпеки.

У межах нашого підходу пропонуємо розглядати ризик економічній безпеці як вірогідність того, що загроза економічній безпеці спричинить конкретні реальні збитки для держави. Своєю чергою, поняття «збитки» варто інтерпретувати як кількісний розмір економічних втрат у разі актуалізації загроз. При цьому дотримуємося позиції $Є$. Ніколаєва стосовно того, що більша увага до ризиків (на додаток до загроз) і ширше застосування підходів ризикології могли би сприяти кращому розумінню й аналізу негативних чинників економічної безпеки та формуванню нової парадигми забезпечення економічної безпеки на основі упередження загроз, а не їx нейтралізації [38, с. 46].

Опрацьовані в представленому дослідженні ключові поняття теорії економічної безпеки держави не $є$ вичерпними. Проте в руслі холістичного бачення та розуміння феномену економічної безпеки держави вони створюють цілісну систему базових дефініцій, яка дає змогу сформулювати методологічні засади цієї дисципліни.

\section{Висновки}

Комплекс різноманітних чинників зумовив нову потужну хвилю зростання досліджень у рамках теорії економічної безпеки держави. На жаль, через суттєві методологічні вади та проблеми реалізація потенціалу зазначеного наукового напряму суттєво стримується.

Теорія економічної безпеки держави все ще перебуває на етапі становлення важливих елементів, які є невід'ємними складовими частинами зрілої самостійної наукової дисципліни. Формування стабільної методологічної бази теорії економічної безпеки держави, серед іншого, вимагає впровадження системи універсальних базових дефініцій, завдяки яким можна було би виробити спільну платформу для наукових шкіл та окремих науковців, котрі провадять дослідження в рамках екосестейту.

У межах реалізації цього амбітного завдання автором проаналізовано значну кількість різних підходів щодо визначення базових дефініцій. На підставі дослідження їх переваг та недоліків представлено власний підхід до визначення важливих понять: «об’єкт економічної безпеки держави», «суб'єкт забезпечення економічної безпеки держави», «загроза економічній безпеці держави», «системна загроза економічній безпеці держави», «джерело загрози економічній безпеці держави», «виклик економічній безпеці», "ризик економічній безпеці», «збитки економічній безпеці». Вони становлять комплекс чітко окреслених, логічно зумовлених та внутрішньо узгоджених базових дефініцій.

Пропоноване наукове дослідження має на меті актуалізувати в науковому середовищі України конструктивну дискусію щодо подальшого вдосконалення та уточнення базових дефініцій у рамках теорії економічної безпеки держави. Особлива увага має бути приділена тому, щоб запропоновані поняття отримали підтримку наукової спільноти та стали загальноприйнятими поміж різними науковими школами. Цим завданням підпорядковуватимуться подальші наукові студіі. 


\section{Список використаних джерел}

1. Жаліло Я. А. До формування категоріального апарату науки про економічну безпеку. Стратегічна панорама. 2004. № 3. С. 97-104.

2. Абалкин Л. И. Экономическая безопасность России: угрозы и их отражение. Вопросы экономики. 1994 . № 12. C. 4-16.

3. Илларионов А. Критерии экономической безопасности. Вопросы экономики. 1998. № 10. С. 35-58.

4. Пирожков С. І. Методичні рекомендації щодо оцінки рівня економічної безпеки України. Київ : НІПМБ, 2003. $42 \mathrm{c}$.

5. Сухоруков А. І., Мошенський С. 3., Петрук О. М. Національна економічна безпека. Житомир : Рута, 2010. $384 \mathrm{c}$.

6. Ляшенко О. М. Концептуалізація управління економічною безпекою підприємства : монографія. 2-ге вид., переробл. Київ : НІСД, 2015. 348 с.

7. Jiang Y. Economic Security: Redressing Imbalance. China Security. 2007. Vol. 3. No 2. Pp. 66-85.

8. Єрмошенко М. М. Фінансова безпека держави: національні інтереси, реальні загрози, стратегія забезпечення. Київ : КНТЕУ, 2001.

9. Губський Б. В. Економічна безпека України: методологія виміру, стан і стратегія забезпечення : монографія. Київ : ДП «Укрархбудінфор», 2001. 122 с.

10. Савин В. А. Некоторые аспекты экономической безопасности России. Международньй бизнес России. 1995. № 9. С. 22-26.

11. Сак Т. В. Економічна безпека України: поняття, структура, основні тенденції. Інноваційна економіка. 2013. № 6. С. 336-340.

12. Сенчагов В. О сущности и основах стратегии экономической безопасности России. Вопросы экономики. 1995. № 1. С. 97-106.

13. Пастернак-Таранушенко Г. А. Економічна безпека держави. Методологія забезпечення : монографія. Київ : Київський економічний інститут менеджменту, 2003. 320 с.

14. Економічна безпека України: сутність і напрями забезпечення : монографія / В. Т. Шлемко, І. Ф. Бінько. Київ : НІСД, 1997. 144 с.

15. Андрійчук В. Г. Економічна безпека України: стан, критерії виміру та превентивні заходи їі зміцнення. Економіка, фінанси, право. 2013. № 6. С. 12-17.

16. Stachowiak Z. Bezpieczeństwo ekonomiczne. In Stankiewicz W. (red.). Ekonomika obrony. Warszawa: Akademia Obrony Narodowej, 1994. S. 189.

17. Raczkowski K. Percepcja bezpieczeństwa ekonomicznego i wyzwania dla zarządzania nim w XXI wieku. In Raczkowski K. (red.). Bezpieczeństwo ekonomiczne. Wyzwania dla zarządzania państwem. Warszawa: Wolters Kluwer, 2012.

18. Губарєва I. О., Доровськой В. А. Теоретичне визначення змісту поняття «економічна безпека». Науковий вісник Львівського державного університету внутрішніх справ. 2009. № 2. С. 31-40.

19. Гончарук Я. А., Флейчук М. І. Диференціація підходів до визначення аналізу категорії «економічна безпека держави». Науковий вісник Львівського державного університету внутрішніх справ. 2009. № 2. URL: http:// www.nbuv.gov.ua/portal/Soc_Gum/Nvldu_e/2009_2/index.htm (дата звернення: 15.09.2021).

20. Бойко В. В. Еволюція розвитку та сутність економічної безпеки держави. Вісник Хмельницького національного університету. Економічні науки. 2015. № 4. Т. 1. С. 162-167.

21. Предборський В. А. Економічна безпека держави : монографія. Київ : Кондор, 2005. 391 с.

22. Мунтіян В. І. Економічна безпека України. Київ : КВШ, 1998. 462 с.

23. Економіка та економічна безпека держави. Теорія та практика: монографічний навчальний посібник/ С. Давиденко, О. Єгорова, В. Приходько, П. Матішак, Я. Голоніч та ін. Ужгород, 2017.

24. Духов В. Є. Системотворчий чинник економічної безпеки держави. Наукові записки ХЕПУ. 2005. № 1 (2), квітень. С. 154-159.

25. Економічна безпека держави: сутність та напрями формування : монографія / Л. С. Шевченко, О. А. Гриценко, С. М. Макуха та ін. / за ред. др-а екон. наук, проф. Л. С. Шевченко. Харків : Право, 2009. 312 с.

26. Власюк О. С. Економічна безпека України в умовах ринкових трансформацій та антикризового регулювання. Київ : ДННУ «Академія фінансового управління», 2011. 474 с.

27. Про затвердження Методичних рекомендацій щодо розрахунку рівня економічної безпеки України: Наказ Міністерства економічного розвитку і торгівлі України від 29.10.2013 № 1277. URL: http://cct.com. ua/2013/29.10.2013_1277.htm7 (дата звернення: 20.03.2020).

28. Кортунов С. В. Диалектика национальной и международной безопасности: некоторые методологические проблемы. Политические исследования. 2009. № 1. 
29. Большой экономический словарь / под. ред. А. Н. Азрилияна. 7-е изд., доп. М. : Институт новой экономики, 2008. 1472 c.

30. Олейников Е. А. Экономическая и национальная безопасность. М. : Экзамен, 2005.766 с.

31. Экономическая и национальная безопасность : учебник / под ред. Л. П. Гончаренко. М. : ЗАО «Издательство Экономика», 2007. 543 с.

32. Румянцева Е. Е. Новая экономическая энциклопедия. 2-е изд. М. : ИНФРА-М, 2006.810 с.

33. Mkrtchyan T. M. State Economic Security System and its Components. 2015. URL: http://dx.doi.org/10.15242/ ICEHM.ED915 (дата звернення: 27.05.2021).

34. Сергунин А. А. Международная безопасность: новые подходы и концепты. Политические исследования. 2005. № 6. C. 127.

35. Кузьменко А. Проблеми відповідності стратегії та системи забезпечення безпеки України національним потребам. Юридичний журнал. 2006. № 10. С. 84-85.

36. Пироженко В. Методологія операціоналізації основних понять національної безпеки: гуманітарна складова. Політичний менеджмент. 2006. № 3. С. 21-34.

37. Вітлінський В. В., Великоіваненко Г. І. Ризикологія в економіці та підприємництві : монографія. Київ : КНЕУ, 2004. С. 5.

38. Ніколаєва О. М. Місцеві фінанси : навч. посіб. Київ : Центр навчальної літератури, 2013.354 с.

\section{References}

1. Zhalilo, Ya. A. (2004). To the formation of the categorical apparatus of the science of economic security. Strategična panorama, 3, 97-104 [in Ukrainian].

2. Abalkin, L. I. (1994). Economic security of Russia: threats and their reflection. Issues of Economics, 12, 4-16 [in Russian].

3. Illarionov, A. (1998). Criteria of economic security. Issues of Economics, 10, 35-58 [in Russian].

4. Pyrozhkov, S. I. (2003). Methodical recommendations for assessing the level of economic security of Ukraine. Kyiv: NIPMB, 42 p. [in Ukrainian].

5. Sukhorukov, A. I., Moshensky, S. Z., \& Petruk, O. M. (2010). National economic security. Zhytomyr: Ruta, 384 p. [in Ukrainian].

6. Liashenko, O. M. (2015). Conceptualization of management of economic security of the enterprise. Kyiv: NISS, 348 p. [in Ukrainian].

7. Jiang, Y. (2007). Economic Security: Redressing Imbalance. China Security. Vol. 3. No 2. Pp. $66-85$ [in English].

8. Yermoshenko, M. M. (2001). Financial security of the state: national interests, real threats, security strategy. Kyiv: KNTEU [in Ukrainian].

9. Gubskyi, B. V. (2001). Economic security of Ukraine: measurement methodology, state and strategy of provision. Kyiv: SE «Ukrarkhbudinfor», 122 p. [in Ukrainian].

10. Savin, V. A. (1995). Some aspects of Russia's economic security. International Business in Russia, 9, 22-26 [in Russian].

11. Sak, T. V. (2013). Economic security of Ukraine: concept, structure, main tendencies. Innovative Economy, 6, 336340 [in Ukrainian].

12. Senchagov, V. (1995). On the essence and foundations of Russia's economic security strategy. Issues of Economics, 1 , 97-106 [in Russian].

13. Pasternak-Taranushenko, G. A. (2003). Economic security of the state. Support methodology. Kyiv: Kyiv Economic Institute of Management, 320 p. [in Russian].

14. Shlemko, V. T., \& Binko, I. F. (1997). Economic security of Ukraine: essence and directions of maintenance. Kyiv: NISS, 144 p. [in Ukrainian].

15. Andriichuk, V. G. (2013). Economic security of Ukraine: state, measurement criteria and preventive measures to strengthen it. Economics, Finance, Law, 6, 12-17 [in Ukrainian].

16. Stachowiak, Z. (1994). Bezpieczeństwo ekonomiczne. In Stankiewicz, W. (Red.). Ekonomika obrony. Warszawa: Akademia Obrony Narodowej. S. 189 [in Polish].

17. Raczkowski, K. (2012). Percepcja bezpieczeństwa ekonomicznego i wyzwania dla zarządzania nim w XXI wieku. In Raczkowski, K. (Red.). Bezpieczeństwo ekonomiczne. Wyzwania dla zarzadzania państwem. Warszawa: Wolters Kluwer [in Polish].

18. Gubareva, I. O., \& Dorovskoi, V. A. (2009). Theoretical definition of the meaning of «economic security». Scientific Bulletin of Lviv State University of Internal Affairs, 2, 31-40 [in Ukrainian].

19. Goncharuk, Ya. A., \& Fleichuk, M. I. (2009). Differentiation of approaches to the definition of the analysis of the category «economic security of the state». Scientific Bulletin of Lviv State University of Internal Affairs, 2. nbuv.gov.ua. http://www.nbuv.gov.ua/portal/Soc_Gum/Nvldu_e/2009_2/index.htm [in Ukrainian]. 
20. Boyko, V. V. (2015). Evolution of development and essence of economic security of the state. Bulletin of Khmelnytsky National University. Economic Sciences, 4. Vol. 1. Pp. 162-167 [in Ukrainian].

21. Predborskyi, V. A. (2005). Economic security of the state. Kyiv: Condor, 391 p. [in Ukrainian].

22. Muntian, V. I. (1998). Economic security of Ukraine. Kyiv: KVSH, 462 p. [in Ukrainian].

23. Davydenko, S., Yehorova, O., Prykhodko, V., Matishak, P., Holonich, Ya., at al. (2017). Economy and economic security of the state. Theory and practice. Uzhhorod [in Ukrainian].

24. Dukhov, V. E. (2005, April). System-forming factor of economic security of the state. Scientific Notes of HEPU, 1(2), 154-159 [in Ukrainian].

25. Shevchenko, L. S. (Ed.), Hrytsenko, O. A., Makukha, S. M., et al. (2009). Economic security of the state: essence and directions of formation. Kharkiv: Pravo, 312 p. [in Ukrainian].

26. Vlasiuk, O.S. (2011). Economic security of Ukraine in the conditions of market transformations and anti-crisis regulation. Kyiv: "Academy of Financial Management», 474 p. [in Ukrainian].

27. On approval of Methodical recommendations for calculating the level of economic security of Ukraine: Order of the Ministry of Economic Development and Trade of Ukraine from 2013, October 29, № 1277. (2013). cct.com.ua. Retrieved March 03, 2020 from http://cct.com.ua/2013/29.10.2013_1277.htm7 [in Ukrainian].

28. Kortunov, S. V. (2009). Dialectics of national and international security: some methodological problems. Political Research, 1 [in Russian].

29. Azriliyan, A. N. (Ed.). (2008). Large Economic Dictionary. Moscow: Institute of New Economy, 1472 p. [in Russian].

30. Oleynikov, E. A. (2005). Economic and national security. Moscow: Ekzamen, 766 p. [in Russian].

31. Goncharenko, L. P. (Ed.). (2007). Economic and national security. Moscow: ZAO «Izdatelstvo Ekonomika», 543 p. [in Russian].

32. Rumyantseva, E. E. (2006). New economic encyclopedia. 2nd ed. Moscow: INFRA-M, 810 p. [in Russian].

33. Mkrtchyan, T. M. (2015). State Economic Security System and its Components. http:// dx.doi.org/10.15242/ICEHM. ED915 [in English].

34. Sergunin, A. A. (2005). International security: new approaches and concepts. Political Research, 6, 127 [in Russian].

35. Kuzmenko, A. (2006). Problems of conformity of strategy and system of security of Ukraine to national needs. Legal Journal, 10, 84-85 [in Ukrainian].

36. Pyrozhenko, V. (2006). Methodology of operationalization of basic concepts of national security: humanitarian component. Political Management, 3, 21-34 [in Ukrainian].

37. Vitlinskyi, V. V., \& Velykoivanenko, G. I. (2004). Risk science in economics and entrepreneurship. Kyiv: KNEU, p. 5 [in Ukrainian].

38. Nikolaieva, O. M. (2013). Local finances. Kyiv: Tsentr navchalnoi literatury, 354 p. [in Ukrainian]. 